\title{
Peran Humas Perguruan Tinggi Negeri Badan Hukum dalam Implementasi Kebijakan Keterbukaan Informasi
}

\author{
Eny Ratnasari ${ }^{1}$, Agus Rahmat ${ }^{2}$, dan FX. Ari Agung Prastowo ${ }^{3}$ \\ ${ }_{1,2,3}$ Universitas Padjadjaran
}

\begin{abstract}
ABSTRAK
Penelitian ini bertujuan untuk mengetahui peran Humas Perguruan Tinggi Negeri Badan Hukum (PTN BH) dalam implementasi kebijakan keterbukaan informasi, dengan fokus kajian penelitian mengenai peran humas dalam implementasi Undang - Undang Nomor 14 Tahun 2008 tentang Keterbukaan Informasi Publik pada Humas Perguruan Tinggi Negeri Badan Hukum (PTN BH) di Kota Bandung yaitu Institut Teknologi Bandung, Universitas Pendidikan Indonesia, dan Universitas Padjadjaran. Peneliti ingin mengetahui peran humas PTN BH di kota Bandung sebagai penasehat ahli, fasilitator komunikasi, fasilitator proses pemecahan masalah, dan teknisi komunikasi dalam implementasi kebijakan keterbukaan informasi. Peneliti menggunakan studi deskriptif dengan jenis data kualitatif. Pengumpulan data dilakukan dengan melalui wawancara mendalam, observasi, studi dokumentasi atau studi pustaka. Temuan dari penelitian ini menunjukkan bahwa pada tiga Perguruan Tinggi Negeri Badan Hukum di kota Bandung sudah melaksanakan peran yang dimilikinya berupa implementasi kebijakan keterbukaan informasi, berperan sebagai penasehat ahli bidang komunikasi, menjadi fasilitator komunikasi dalam proses pemecahan masalah serta menjadi teknisi komunikasi. Namun demikian, ada beberapa hal yang menuntut peningkatan guna menjadikan lebih baik. Karenanya peneliti menyarankan agar masing - masing humas PTN BH di kota Bandung meningkatkan aktivitas evaluasi mengenai keterbukaan informasi yang dilaksanakannya, lebih mensosialisasikan kewajiban untuk membuka informasi pada publik internal, dan membuat struktur birokrasi Pejabat Pengelola Informasi dan Dokumentasi yang lebih efisien.
\end{abstract}

Kata-kata Kunci: Humas; implementasi; informasi publik; keterbukaan informasi; peran humas

\section{The Role of Public Relations of State Universities in the Implementation of Information Transparency Policy}

\begin{abstract}
This study aims to find the role of Public Relations of State Universities in the implementation of information transparency policy, with a focus of research on the role of public relations in the implementation of Law Number 14 Year 2008 on Public Information Transparency by Public Relations of State Universities of Bandung Institute of Technology, Universitas Pendidikan Indonesia, and Universitas Padjadjaran. Researchers want to find the role of public relations officers as an expert advisor, communication facilitators, facilitators of problem-solving process, and communication technicians in the implementation of transparency policy information. Researchers used descriptive studies with qualitative data types. Data collecting is conducted through in-depth interview, observation, documentation study or literature study. The findings of this study indicate that the three State Universities have implemented its role in the implementation of information transparency policy, acting as a communication consultant expert, a facilitator of communication in the process of problem solving and become a communication technician. However, there are some things that demand improvement to make it better. Therefore, the researcher suggested that each public relations officer in the university increases the evaluation activity on information transparency, socialize the obligation to disclose information to the internal public, and make more efficient bureaucracy structure of the Information and Documentation Management Officer.
\end{abstract}

Keywords: Implementation; information disclosure; public information; public relations

Korespondensi: Eny Ratnasari. Universitas Padjadjaran, Jl. Raya Bandung-Sumedang Km 21, Jatinangor 45363.Email: ratnasarieny@gmail.com 


\section{PENDAHULUAN}

Indonesia merupakan salah satu negara di dunia yang menganut sistem demokrasi yang sedang berjuang untuk mencapai good governance. Menyadari pentingnya keterbukaan informasi untuk keberlangsungan negara, dibuatlah kebijakan yang tertuang dalam Undang - Undang Nomor 14 Tahun 2008 tentang Keterbukaan Informasi Publik. UU No. 14 Tahun 2008 mewajibkan semua badan publik membuka akses informasi bagi publik.

Berdasarkan hasil pemeringkatan badan publik yang dilakukan oleh Komisi Informasi Pusat pada tahun 2016, nilai ratarata keterbukaan informasi Perguruan Tinggi Negeri (PTN) tergolong dalam kategori kurang informatif dengan nilai 56,00. Artinya, tingkat kepatuhan PTN terhadap UU KIP masih rendah. Rendahnya tingkat kepatuhan tersebut menjadi tamparan keras bagi PTN yang merupakan garis terdepan dalam mengimplementasikan dan mendorong keterbukaan. Selain karena masuk dalam kategori badan publik, PTN adalah bagian utama dari sistem kaderisasi sumber daya manusia sebuah negara.

Peraturan Pemerintah Nomor 61 Tahun 2010 tentang Pelaksanaan UU KIP menjelaskan mengenai kewajiban humas untuk membantu badan publik mengimplementasikan UU KIP. Humas dianggap sebagai pihak yang paling tepat karena humas memahami kebutuhan organisasi dalam menjaga reputasi. Tantangan peran humas akan keterbukaan informasi semakin terasa pada PTN terlebih Perguruan Tinggi Negeri Badan Hukum (PTN BH). PTN BH memiliki otonomi pengelolaan. Sehingga keterbukaan informasi PTN BH harus menjunjung tinggi prinsip transparansi dan akuntabilitas sesuai dengan UU KIP agar dapat menjadi contoh dan patut diteladani oleh badan publik lain khususnya PTN.

Di kota Bandung terdapat tiga PTN yang sudah berstatus Badan Hukum yakni Institut Teknologi Bandung (ITB), Universitas Pendidikan Indonesia (UPI), dan Universitas Padjadjaran (Unpad). Ketiga PTN BH ini memiliki bagian humas dengan penamaan, struktur, dan garis koordinasi yang berbedabeda. Disamping itu, pejabat pengelola informasi publik di ketiga PTN BH ini diterapkan secara berbeda-beda pula.

Institut Teknologi Bandung (ITB) pernah dianggap tidak transparan pada tahun 2015 oleh sebuah Lembaga Swadaya Masyarakat (LSM). ITB dianggap korupsi terhadap dana beasiswa dari pemerintah provinsi Jabar. LSM menuntut transparansi dana terkait dengan dana beasiswa dari Pemerintah Provinsi Jawa Barat dengan menggelar aksi demonstrasi. Dalam pemeringkatan keterbukaan informasi yang dilakukan komisi informasi pusat tahun 
2016, ITB untuk pertama kalinya masuk dalam peringkat 10 besar setelah sebelumnya tidak masuk 20 besar.

Mahasiswa Universitas Pendidikan Indonesia (UPI) pada Agustus 2016 melakukan aksi demonstrasi terkait dengan tidak adanya transparansi dan akuntabilitas terkait kebijakan mengenai seleksi mandiri dan UKT. Seperti yang tertulis dalam artikel yang dilansir dalam website Badan Eksekutif Mahasiswa UPI, informasi mengenai penjabaran dari tiap-tiap komponen biaya pendidikan seleksi mandiri pun tidak jelas. Dalam pemeringkatan yang pernah dilakukan komisi informasi pusat sampai dengan tahun 2016, UPI tidak masuk peringkat 10 besar.

Universitas Padjadjaran pernah didemo pada Juni 2016 oleh petugas Kebersihan dan Kenyamanan Lingkungan (K3L) Unpad. Penyebab utama demonstrasi adalah tidak adanya sosialisasi pemotongan jumlah pegawai K3L oleh pihak Universitas Padjadjaran. Terlebih berita ini tersiar oleh beberapa media di Jawa Barat dan dipublikasikan dalam website Universitas Padjadjaran. Pada pemeringkatan badan publik yang dilakukan komisi informasi pusat pada tahun 2016, Universitas Padjadjaran yang baru menyandang statuta PTN BH pada tahun 2014 turun ke peringkat keempat setelah sebelumnya masuk dalam peringkat tiga besar.

Uraian tersebut menunjukkan bahwa peran humas masing-masing PTN BH yang ada di kota Bandung masih kurang dalam implementasi keterbukaan informasi publik khususnya menyediakan informasi yang wajib disediakan dan diumumkan (UU No. 14 Tahun 2008 Bab IV) dan tentang mekanisme memperoleh informasi yang tertuang (UU No. 14 Tahun 2008 Bab VI). Mekanisme memperoleh informasi melalui PPID seharusnya disosialisasikan oleh humas kepada stakeholder.

Humas seharusnya melakukan peran sebagai manajer humas dalam membantu manajemen pada PTN BH yang bersangkutan untuk mencapai keterbukaan informasi publik. Berdasarkan konsep yang disampaikan oleh Dozier \& James (1995) dalam Ruslan (2014) humas sebagai manajer humas memiliki peran sebagai penasehat ahli (expert prescriber), fasilitator komunikasi (communication facilitator), fasilitator proses pemecahan masalah (problem solving process facilitator), dan technician communication (teknisi komunikasi). Namun peran-peran yang seharusnya dilakukan oleh masing-masing humas PTN BH di kota Bandung belum maksimal.

Public relations (PR) atau yang di Indonesia sering disebut Hubungan Masyarakat (Humas) merupakan profesi dan organisasi yang tengah berkembang di masyarakat. PR adalah jembatan yang membangun relasi yang baik dengan 
publik PR itu sendiri. Pengertian tentang public relations yang dikemukakan oleh Frank Jefkins menyebutkan tentang bagaimana public relations memiliki keterkaitan dengan tujuan institusi. Public relations adalah semua bentuk komunikasi yang terencana, baik itu ke dalam maupun ke luar, antara suatu organisasi dengan semua khalayaknya dalam rangka mencapai tujuan-tujuan spesifik yang berlandaskan pada saling pengertian” (dalam Gifari, 2017).

Praktisi public relations memiliki peranan penting untuk menangani krisis karena mengingat masa krisis dapat berdampak negatif terhadap citra perusahaan. Dapat dikatakan public relations adalah fungsi manajemen yang strategis.

Agar fungsi strategis tersebut berjalan dengan baik, sebaiknya posisi public relations berada di bawah pimpinan puncak agar memiliki wewenang yang memungkinkan fungsinya dapat dijalankan secara efektif mengingat dampak negatif dan kerugian besar bahkan citra perusahaan akan terganggu ketika terjadinya krisis (Jessica, 2018). Penelitian ini diharapkan dapat menjelaskan gambaran serta menjadi masukan terkait dengan peran Humas PTN BH di Kota Bandung dalam melakukan upaya mencapai implementasi UU No. 14 Tahun 2008 tentang keterbukaan informasi publik di badan publik tersebut.

\section{METODE PENELITIAN}

Penelitian ini menggunakan metode deskriptif. Metode deskriptif adalah suatu metode dalam meneliti status sekelompok manusia, suatu objek, suatu set kondisi, suatu sistem pemikiran, ataupun suatu kelas peristiwa pada masa sekarang. Penelitian deskriptif hanya memaparkan suatu situasi atau peristiwa. Penelitian ini tidak mencari suatu hubungan, tidak menguji hipotesis atau membuat prediksi (Ardianto, 2011).

Pada konteks seperti yang telah disebutkan di atas, Humas Perguruan Tinggi Negeri Badan Hukum di kota Bandung pada dasarnya menyadari bahwa sudah merupakan kewajiban humas badan publik untuk selalu berupaya mengimplementasikan Undang-Undang Keterbukaan Informasi Publik. Oleh karena itu, peneliti mencoba untuk menggambarkan bagaimana peran Humas Perguruan Tinggi Negeri Badan Hukum di kota Bandung dalam upaya mengimplementasikan Undang-Undang Nomor 14 Tahun 2008 Tentang Keterbukaan Informasi Publik pada Perguruan Tinggi Negeri Badan Hukum di kota Bandung. Disamping itu, peneliti akan mencoba untuk menganalisis kendala-kendala yang dihadapi Humas Perguruan Tinggi Negeri Badan Hukum dalam mengimplementasikan Undang-Undang Keterbukaan Informasi Publik. 
Penelitian deskriptif mempelajari masalahmasalah dalam masyarakat, serta tata cara yang berlaku dalam masyarakat serta situasisituasi tertentu, termasuk tentang kegiatankegiatan, sikap-sikap, pandangan-pandangan, serta proses-proses yang sedang berlangsung. Adakalanya peneliti mengadakan klasifikasi serta penelitian terhadap fenomena-fenomena dengan menetapkan suatu standar atau suatu landasan tertentu (Nazir, 2006).

Dalam penelitian deskriptif, peneliti mendeskripsikan suatu fenomena dengan mengeksplorasi dan memberikan gambaran lengkap yang berkaitan dengan masalah dan fenomena yang diteliti. Penelitian deskriptif dilakukan untuk menggambarkan secara sistematis mengenai objek dan subjek yang diteliti.

Teknik yang digunakan dalam penentuan informan ini adalah purposive sampling. Purposive sampling adalah teknik penentuan sampel dengan pertimbangan tertentu.

Sampel ini lebih cocok digunakan untuk penelitian studi deskriptif atau penelitianpenelitian yang tidak menggunakan generalisasi. Key informant akan menjadi narasumber bagi pengumpulan data dipilih berdasarkan aktivitas mereka dan kesediaan mereka untuk mengeksplorasi pengetahuan dan pengalaman mereka secara sadar. Peneliti dapat memilih informan atau bisa juga informan yang mengajukan secara sukarela.

\section{HASIL DAN PEMBAHASAN}

Salah satu peran public relations dalam organisasi menurut Dozier dan James (dalam Ruslan, 2014) adalah sebagai penasehat ahli (expert prescriber). Sebagai penasehat ahli (expert prescriber), public relations dalam menjalankan peranan sebagai penentu ahli adalah mendefinisikan masalah, membuat perencanaan program dan bertanggung jawab penuh atas pelaksanaan program komunikasi.

Sebagai penasehat ahli (expert prescriber), humas ketiga PTN BH di Kota Bandung, ITB, UPI, dan Unpad memberikan berbagai saran kepada manajemen dan pimpinan dalam upaya implementasi kebijakan keterbukaan informasi. Saran dari humas pada masing-masing PTN $\mathrm{BH}$ di kota Bandung sangat penting dalam upaya mencapai implementasi keterbukaan informasi di masing-masing perguruan tinggi. Hal ini dikarenakan humas lebih mengetahui pelaksanaan keterbukaan informasi dan mengetahui kondisi yang harus dihadapi untuk melakukan keterbukaan informasi.

Ketiganya memiliki kesamaan yakni tidak berada di bawah pimpinan tertinggi perguruan tinggi (Rektor) langsung. Humas ITB, UPI, dan Unpad harus melewati satu tahap terlebih 
dahulu sebelum menyampaikan saran kepada pimpinan tertinggi PTN BH. Meski tidak berada di bawah rektor langsung, Humas dari ketiga PTN BH di kota Bandung tetap masuk ke dalam unsur pimpinan. Sehingga humas tidak hanya sebagai pelaksana tetapi juga dapat ikut terlibat di dalam pengambilan keputusan. Oleh karena itu, peran penasehat ahli di ketiga PTN BH ini tidak sulit dilakukan.

Humas ITByang berada dibawah koordinasi memberikan saran pada Wakil Rektor Bidang Administrasi Umum, Alumni dan Komunikasi (WRAAK). Kemudian Humas UPI memberikan saran kepada Sekretaris Eksekutif. Sedangkan Humas Unpad memberikan saran pada Wakil Rektor Bidang Tata Kelola dan Sumber Daya. Dalam tata kelola Perguruan Tinggi Negeri Badan Hukum, Sekretaris Eksekutif dan Wakil Rektor sama kedudukannya hanya nomenklaturnya saja yang berbeda.

Humas memberikan saran dalam proses pembentukan standar prosedur pelayanan informasi di masing-masing PTN BH. Agar pelayanan informasi dapat dilakukan dengan maksimal, maka harus dibentuk standar mengenai pelayanan informasi di masingmasing PTN BH. Kemudian humas memberikan saran mengenai bentuk dari PPID yang paling ideal di masing- masing PTN BH. Humas pada masing-masing PTN BH di kota Bandung menyarankan agar PPID di PTN BH melekat pada bagian humas. Hal ini dikarenakan humas sebagai bagian yang lebih menguasai selama ini berhadapan dengan publik, melayani informasi, dan lebih paham mengenai pelaksanaan keterbukaan informasi publik.

Humas masing-masing PTN BH di kota Bandung memberikan saran kepada pimpinan masing-masing terkait dengan pembentukan sistem pelayanan informasi di lingkungan masing -masing PTN BH. Pemberian saran ini dilakukan setelah humas di tiga PTN BH di kota Bandung mempelajari sistem pelayanan informasi dari para pemenang dalam pemeringkatan keterbukaan informasi publik yang dilakukan oleh komisi informasi pusat. Akhirnya, humas PTN BH di kota Bandung memberikan saran pimpinan masing-masing untuk membentuk sistem pelayanan informasi secara online.

SOP yang digunakan oleh ITB dan Unpad pada akhirnya mengacu pada UU No. 14 Tahun 2008 tentang keterbukaan informasi publik beserta peraturan turunannya. Namun, Ibu Henny S. Widyaningsih yang merupakan akademisi dan Komisioner Komisi Informasi Pusat berpendapat bahwa;

"Perguruan Tinggi Negeri Badan Hukum tetap harus memiliki peraturan internal sendiri. Ia menuturkan bahwa PTN BH tetap harus memiliki peraturan internal sendiri tentang standar layanan informasi pada PTN BH tersebut, karena arena PTN BH telah diberi kewenangan penuh dengan pejabat pengelola informasi dan dokumentasi utamanya boleh dari PTN BH 
yang bersangkutan" (Wawancara dengan Henny S. Widyaningsih, 2017).

Dalam hal ini telah diatur dalam Peraturan Menristekdikti bahwa PPID Utama PTN Badan Hukum dijabat oleh Wakil Rektor / Sekretaris Universitas / Sekretaris Institut / Sekretaris Eksekutif / pejabat yang membidangi hubungan masyarakat atau pengelolaan informasi pada PTN Badan Hukum.

Dozier dan James (1995) mengungkapkan peran humas selanjutnya adalah sebagai fasilitator komunikasi (communication facilitator). Dalam hal ini, public relations bertindak sebagai penghubung, penerjemah, dan mediator antara organisasi dan publik. Humas PTN BH di kota Bandung sebagai fasilitator komunikasi berperan sebagai jembatan komunikasi antara organisasi dengan publiknya. Selain itu, humas menjadi mediator ketika terjadi miss communication antara organisasi dengan publiknya. Kemudian humas perlu melakukan mediator bagi publik internal dan publik eksternal organisasi yang diwakilinya. Humas juga bertugas menjadi mediator bagi publik internal yaitu bagian-bagian yang ada di organisasi yang diwakilinya. Humas pun perlu menjadi mediator antara organisasi dan publik eksternalnya yaitu masyarakat luas.

Dalam upaya mencapai implementasi keterbukaan informasi publik di PTN BH di kota Bandung, Humas ITB atau Direktorat
Hubungan Masyarakat dan Alumni ITB berkoordinasi dengan intens bersama dengan direktorat dan lembaga lain yang berada di bawah naungan Kantor Wakil Rektor Bidang Administrasi Umum, Alumni dan Komunikasi. Sehingga bagian-bagian yang harus terlibat antara lain Direktorat Hubungan Masyarakat dan Alumni, Direktorat Administrasi Umum, Direktorat Sistem dan Teknologi Informasi, dan Lembaga Layanan Hukum.

Humas UPI atau Kantor Hubungan Masyarakat UPI berada di bawah naungan Sekretaris Universitas / Sekretaris Eksekutif UPI. Di bawah naungan Sekretaris Eksekutif UPI. Humas UPI harus berkoordinasi dengan Dekan Fakultas, Direktur Sekolah Pascasarjana, Direktur Kampus UPI di Daerah, Ketua LPPM, Tim/Staf Ahli, Kepala Biro Hukum dan Kesekretariatan, Kepala Arsip Universitas, dan Kepala UPT Keamanan dan Ketertiban Kampus.

Selanjutnya, Humas Unpad atau Direktorat Tata Kelola dan Komunikasi Publik berada di bawah koordinasi Wakil Rektor Bidang Tata Kelola dan Sumber Daya. Namun, dalam hal ini Humas Unpad sebagai PPID harus berkoordinasi dengan Direktorat Teknologi dan Sistem Informasi. Direktorat Teknologi dan Sistem Informasi bukan berada di bawah naungan Wakil Rektor Bidang Tata Kelola dan Sumber Daya. 
Sering kali informasi yang diminta oleh para pemohon informasi belum tersedia di PPID. Sehingga PPID harus meminta terlebih dahulu informasi tersebut kepada bagian yang memproduksi dan mengelola informasi. Dalam proses permintaan informasi dari PPID ke bagian tersebut, humas biasanya memfasilitasi dengan mengirimkan email kepada bagian tersebut. Dapat juga humas berkomunikasi via telepon atau aplikasi pesan Whatsapp antar pimpinan. Hal ini dilakukan agar permohonan informasi cepat terpenuhi. Humas dan PPID tidak bisa dipisahkan dan saling melekat dalam pelaksanaan keterbukaan informasi di masingmasing PTN BH di kota Bandung.

Komunikasi dapat berjalan efektif dengan proses penyampaian informasi dilakukan oleh komunikator yang meyakinkan. Masingmasing Kepala Humas pada Perguruan Tinggi Negeri Badan Hukum di kota Bandung ditunjuk sebagai Koordinator Pelaksana Pejabat Pengelola Informasi dan Dokumentasi (PPID) yang bertugas berkomunikasi dengan publik dalam program-pelayanan informasi publik dalam proses pelayanan informasi publik. Ada kesamaan dari ketiga Perguruan Tinggi Negeri Badan Hukum di kota Bandung yaitu menurut penuturan masing-masing Kepala Humas dari ITB, UPI, dan Unpad, penunjukan dirinya sebagai PPID ditentukan oleh pimpinan.

Terkait dengan penunjukan humas sebagai
PPID, Henny S. Widyaningsih menjelaskan bahwa dalam Undang-Undang telah disebutkan bahwa PPID merupakan pejabat yang melakukan pelayanan informasi. Suatu hal yang amat baik apabila PPID dijabat oleh kepala humas karena humas adalah bagian yang melakukan pelayanan informasi dalam sebuah organisasi. Beliau juga menekankan bahwa humas harus menjadi bagian dari tim PPID dan tidak boleh diluar dari tim PPID. Tim PPID yang dimaksud sesuai dengan peraturan komisi informasi adalah tim pengumpulan informasi, tim pelayanan informasi, tim pendokumentasian informasi, dan tim sengketa informasi.

Peraturan Pemerintah Nomor 61 Tahun 2010 Pasal 21 ayat 2 menyebutkan bahwa "Dalam hal PPID belum ditunjuk, tugas dan tanggung jawab PPID dapat dilakukan oleh unit atau dinas di bidang informasi, komunikasi, dan/atau kehumasan.” Dengan demikian PPID bertanggung jawab untuk merencanakan, mengorganisasikan, melaksanakan, mengawasi, dan mengevaluasi penyelenggaraan kegiatan pengelolaan dan pelayanan informasi publik. Berdasarkan tanggung jawab ini, dipilihlah Kepala Humas masing-masing Perguruan Tinggi Negeri Badan Hukum sebagai PPID karena terkait dengan tupoksinya selama ini dalam bidang pelayanan informasi. PPID merupakan pejabat struktural yang ditunjuk untuk melaksanakan tugas dan fungsi 
pengelolaan dan pelayanan informasi publik di lingkungan Perguruan Tinggi Negeri Badan Hukum di kota Bandung. PPID harus memiliki kompetensi dalam bidang pengelolaan dokumen, pengelolaan data, pelayanan informasi, dan kehumasan. Koordinator PPID pelaksana dari ketiga Perguruan Tinggi Negeri Badan Hukum di kota Bandung yaitu ITB, UPI, dan Unpad adalah Kepala Humas pada masingmasing perguruan tinggi.

Disamping itu, komunikasi yang dilakukan dalam peran humas sebagai fasilitator komunikasi adalah komunikasi tatap muka yang dilakukan dalam bentuk desk informasi yang dibagi lagi ke dalam pembagian tugas front office dan back office. Di ITB dan Unpad dalam pelayanan informasi publik terbagi menjadi dua yaitu front office dan back office. Sedangkan di UPI, dalam pelayanan informasi langsung humas merangkap sebagai front office dan back office. Skema mekanisme permohonan informasi seperti ini, konsep front office dan back office hanya inisiatif dari masing-masing PPID di PTN BH yang ada di kota Bandung.

Pada ITB dan Unpad, front office bertugas melayani permintaan informasi publik oleh pemohon informasi, dalam hal ini mencatat tanggal permintaan informasi, nama pemohon informasi, alamat, dan lain sebagainya. Jika di ITB terdapat di Information Center, sedangkan di Unpad terdapat di Unit Layanan Terpadu.
Sedangkan back office akan bertugas dalam penyajian, pendokumentasian, penyiapan, dan lain-lain terhadap informasi publik. Untuk petugas pada desk layanan informasi publik memiliki kompetensi seperti pengetahuan mengenai peraturan perundang-undangan yang terkait dengan keterbukaan informasi publik dan pelayanan publik, keterampilan dan sikap dalam berkomunikasi sehingga dapat menunjang dalam melaksanakan tugas pelaksanaan informasi.

Namun, di UPI tidak ada help desk untuk informasi publik. Sehingga apabila ada yang ingin bertanya mengenai informasi tentang UPI, pemohon tersebut harus bertanya langsung ke kantor Humas. Justru pelayanan informasi di UPI dibawah koordinasi Direktorat Akademik. Sehingga terdapat loket-loket pelayanan informasi sejumlah fakultas yang ada di UPI. Namun pelayanan ini hanya ditujukan kepada mahasiswa saja. Sebaiknya, UPI tetap membuat help desk informasi yang berasal dari humas agar alur informasi yang ada di UPI jelas. Humas Perguruan Tinggi Negeri Badan Hukum di kota Bandung sebagai fasilitator pemecahan masalah dalam implementasi kebijakan keterbukaan informasi. Dozier dan James (1995) berpendapat bahwa peran public relations salah satunya adalah sebagai fasilitator pemecah masalah (problem solver facilitator). Dalam hal ini public relations melakukan 
kerja sama dengan manajer lain untuk mendefinisikan dan memecahkan masalah. Praktisi public relations dalam hal ini membantu manajemen memecahkan permasalahan dengan menerapkan proses manajemen mulai dari menganalisa masalah, membuat perencanaan dan melaksanakan serta mengevaluasi.

Pada ketiga PTN BH, bagian internal masing-masing institusi masih belum sadar bahwa PTN BH wajib untuk melakukan keterbukaan informasi sesuai UU KIP. Sehingga masih ada bagian yang ada di internal PTN BH yang belum tersedia memberikan informasi yang mereka produksi, untuk mengatasi hambatan, masing-masing Humas PTN BH di kota Bandung melakukan sosialisasi kepada bagian internal yang ada di masing-masing PTN $\mathrm{BH}$ tentang UU KIP. Kemudian melakukan rapat internal bagian humas untuk mengatasi hambatan yang dihadapi dalam melakukan implementasi UU KIP pada PTN BH di kota Bandung yang waktunya disesuaikan dengan kondisi di lapangan.

Namun, ketiga Humas PTN BH di kota Bandung tidak melakukan evaluasi terhadap kinerja PPID di masing-masing PTN BH. Peneliti melihat tidak dilakukannya evaluasi membuat masing-masing Humas PTN BH terkesan berpuas diri dengan kinerja yang telah mereka lakukan sebagai PPID. Bahkan ada yang menganggap tidak dilakukan evaluasi karena tidak terjadi masalah. Sebaliknya, tidak adanya evaluasi menjadikan masalah untuk masingmasing Humas PTN BH di kota Bandung.

Terdapat kelebihan apabila Kepala Humas sebagai PPID utama karena dikenal dan dipercaya oleh bagian lain dalam organisasi untuk menyampaikan informasi kepada publik. Khususnya pada PTN Badan Hukum, PPID Utama boleh dijabat oleh humas. Namun, pada kenyataan di lapangan terdapat kekurangan karena tetap harus patuh terhadap kebijakan atasan sehingga pernah kesulitan juga mengeluarkan informasi yang sebetulnya harus diinformasikan kepada masyarakat. Kesulitan ini terkait posisi kepala humas dalam struktur masing-masing Perguruan Tinggi Negeri Badan Hukum di kota Bandung yang masih dalam level manajemen tengah/middle management sehingga masih harus patuh terhadap keputusan manajemen atas/top management. Kendala ini dialami oleh ketiga PTN BH di kota Bandung. Secara tertulis di Surat Keputusan Rektor ITB, Kepala Humas ITB menjadi PPID Pelaksana, begitu juga dengan Kepala Humas Unpad. Namun di UPI, Kepala Humasnya menjadi PPID Utama.

Berdasarkan hasil penelitian di lapangan menunjukkan bahwa Kepala Humas ITB dengan Tim PPID ITB cukup kooperatif dalam implementasi kebijakan keterbukaan informasi. Tim tersebut terdiri dari Wakil 
Rektor Administrasi, Alumni, dan Komunikasi, Direktur Administrasi Umum, Direktur Sistem dan Teknologi Informasi, Ketua Lembaga Layanan Hukum. Tim ini terdiri dari para pimpinan sehingga memudahkan koordinasi.

Humas Unpad memiliki tim yang cukup solid untuk implementasi keterbukaan informasi publik. Hal yang peneliti temukan di lapangan adalah PPID Pelaksana yang dijabat oleh Kepala Humas Unpad atau Direktur Tata Kelola dan Komunikasi Publik harus bertindak seperti PPID Utama. Karena Kepala Humas Unpad harus memutuskan dibuka atau tidaknya sebuah informasi karena humas yang lebih mengerti perihal teknis dari implementasi kebijakan keterbukaan informasi publik. Padahal menurut Undang-Undang, kewenangan tersebut hanya boleh dilakukan oleh PPID Utama di Unpad yaitu Wakil Rektor. Diakui oleh beberapa informan bahwa kesadaran dari pimpinan terkait dengan keterbukaan informasi publik ini masih kurang. Permasalahan yang terjadi di Unpad dapat diatasi dengan cara membuat SOP internal yang menguatkan posisi Kepala Humas apabila memang diangkat sebagai PPID Utama di sebuah PTN BH agar kewenangannya bisa penuh. Dengan demikian PPID tersebut dapat memiliki wewenang yang luas untuk memutuskan dan menentukan dibuka dan ditutupnya suatu informasi.

PTN Badan Hukum memiliki keistimewaan tersendiri karena sudah diatur dalam Peraturan Menteri Riset, Teknologi dan Pendidikan Tinggi Nomor 75 Tahun 2016 tentang Layanan Informasi Publik di Lingkungan Kemristekdikti yang langsung menyebutkan PPID Utama PTN BH dijabat oleh Wakil Rektor pada PTN BH. Solusi lain adalah dengan cara memperjelas struktur PPID di badan publik. Hal ini dilakukan untuk lebih memberikan jaminan bagi pemegang jawaban PPID agar dapat bekerja secara maksimal dan terarah. Mengingat tanggung jawabnya yang besar dan berat, maka beberapa instansi bahkan membuat nomenklatur baru yang ditugaskan menjalankan peran khusus PPID di instansi mereka.

Menurut Dozier dan James (dalam Ruslan, 2014) humas memiliki peran sebagai teknisi komunikasi (communication technician). Peranan public relations disini adalah melakukan teknis operasional seperti menulis dan menyunting majalah, menulis siaran pers, karangan khas, artikel, membuat dan mengembangkan situs web, serta produksi berbagai pesan komunikasi. Oleh karena itu, diperlukan keterampilan komunikasi dan jurnalistik.

Humas masing-masing PTN BH di kota Bandung telah melakukan perananya sebagai teknisi komunikasi dengan membuat dan mengembangkan situs website. Website merupakan salah satu sarana online public 
relations yang mendukung kegiatan publikasi. Dalam kaitannya dengan implementasi keterbukaan informasi, website membantu agar publik PTN BH di kota Bandung mengetahui upaya masing-masing perguruan tinggi untuk membuka informasi kepada publik.

Sesuai dengan Standar Operasional Prosedur (SOP) pada badan publik yang diatur dalam UU KIP yang dijabarkan dalam Peraturan Komisi Informasi Nomor 1 Tahun 2010 tentang Standar Layanan Informasi Publik. Dalam peraturan komisi informasi tersebut layanan informasi dibagi menjadi dua yaitu standar layanan informasi melalui pengumuman dan standar layanan informasi melalui permohonan. Dalam hal ini Perguruan Tinggi Negeri Badan Hukum sebagai badan publik diharuskan memberikan layanan informasi publik secara proaktif dengan mempublikasikan informasi publik yang berada dibawah kewenangannya sekurang-kurangnya melalui media papan pengumuman atau situs resmi (website) PTN $\mathrm{BH}$.

Humas ITB telah membuat keputusan yang tepat untuk membentuk dan mengembangkan 2 website. ITB telah memiliki website utama (www.itb.ac.id) dan website khusus untuk pelayanan informasi publik (infopublik.itb. ac.id). Hal ini berguna agar dapat mempermudah publik yang ingin mencari informasi publik di ITB. Selain itu, dengan dibedakannya website antara informasi publik dan website utama ini, dapat mempermudah Humas ITB dalam mengerjakan tugas sebagai humas dan tugas sebagai PPID. Sehingga tidak saling tumpang tindih.

Unpad memiliki website utama (www. unpad.ac.id) dan website pelayanan informasi publik (ppid.unpad.ac.id). Hal ini memudahkan humas untuk bertindak ketika menjadi PPID Unpad. Website utama dan website layanan informasi publik memang saling beriringan, tetapi dalam hal ini Humas memiliki tanggung jawab yang berbeda.

Dengan adanya halaman atau website khusus mengenai informasi publik yang dimiliki oleh ITB dan Unpad akan memudahkan publik untuk mengakses informasi. ITB dan Unpad yang telah memiliki website PPID sendiri berharap bahwa website yang ruang publiknya luas, tanpa batas, dan real time dapat membantu humas dalam implementasi kebijakan keterbukaan informasi publik. Dengan adanya website ini, informasi yang wajib tersedia setiap saat ada, informasi sertamerta, informasi berkala dan informasi yang dikecualikan sesuai dengan perintah UndangUndang telah ada dalam laman tersebut. Humas bekerja sama dengan unit teknologi informasi merancang website yang dapat digunakan dalam proses permohonan informasi dan penyampaian informasi publik dari badan 
publik kepada masyarakat. Ada perancangan website yang dapat memudahkan publik yang ingin mengakses informasi publik dari masingmasing Perguruan Tinggi Badan Hukum di kota Bandung tanpa harus hadir secara tatap muka.

Hal yang menjadi evaluasi bagi ITB dan Unpad yang telah memiliki website khusus untuk informasi publik adalah update konten yang ada dalam website layanan informasi publik harus sering dilakukan. Terutama yang terkait dengan informasi publik yang wajib disediakan dan diumumkan. Sedangkan untuk UPI, peneliti menyarankan agar UPI segera membuat website khusus informasi publik sesuai yang diamanatkan oleh Undang-Undang untuk mempermudah akses informasi publik. Karena website ini menjadi indikator terbuka atau tidaknya informasi di UPI menurut yang diamanatkan dalam undang-undang maupun peraturan menteri. Kemudian segera mengaktifkan kembali media sosial yang mereka miliki. Jika kendala yang ditemui adalah sumber daya, Humas UPI seharusnya dapat melakukan pembagian tugas yang lebih adil dan jelas agar program ini dapat terlaksana.

Saat ini, public relations sudah dihadapkan pada era Masyarakat Ekonomi ASEAN yang sarat dengan kompetisi. Pembentukan, pemeliharaan, dan peningkatan citra menjadi semakin krusial. Pencitraan Perguruan Tinggi Negeri telah merambah hingga kancah internasional. Humas adalah fungsi manajemen yang mengevaluasi opini, sikap, dan perilaku publik, mengidentifikasi kebijakan - kebijakan dan prosedur-prosedur suatu individu atau sebuah organisasi dengan kepentingan publik dan merencanakan serta melaksanakan program aksi untuk memperoleh pengertian dan dukungan publik (Cutlip, 2005).

Rhenald Khasali (2005) pakar manajemen mengutip konsep public relations News yang memebrikan definisi Public relations sebagai fungsi manajemen yang melakukan evaluasi terhadapsikap-sikappublik,mengidentifikasikan kebijakan dan prosedur seseorang/sebuah perusahaan terhadap publiknya, menyusun rencana serta menjalankan program-program komunikasi untuk memperoleh pemahaman dan penerimaan publik.

Cutlip (2005) juga mengungkapkan bahwa hubungan masyarakat merupakan fungsi manajemen yang membentuk dan memelihara hubungan yang saling menguntungkan antara organisasi dan masyarakat yang menjadi sandaran keberhasilan atau kegagalannya. SedangkanAnggoroLinggar (2000) mengatakan bahwa public relations adalah usaha untuk menciptakan hubungan yang harmonis antara suatu badan atau organisasi dengan masyarakat melalui suatu proses komunikasi timbal balik atau dua arah. Hubungan yang harmonis ini timbul dari adanya mutual understanding, 
mutual confidence, dan image yang baik.

Berdasarkan konsep-konsep yang telah disebutkan dapat disimpulkan bahwa humas adalah seni berkomunikasi atau aktivitas komunikasi; sebagai disiplin ilmu sosial dengan perspektif komunikasi; salah satu fungsi manajamen dalam organisasi; menggunakan fungsi manajemen dalam menjalankan komunikasi organisasi dengan publiknya secara timbal balik. Sebagai fungsi manajemen, public relations atau humas memiliki peranan dan fungsi yang berbeda dengan profesi lain. Public relations memiliki tujuan yang khas yakni memperoleh kepercayaan dan dukungan publik baik internal dan eksternal organisasi melalui perencanaan program komunikasi yang strategis. Suatu organisasi dalam pencapaian tujuannya, membutuhkan dukungan dari seluruh karyawan, manajer dan pimpinan serta masyarakat lainnya. Untuk itu, diperlukan komunikasi yang persuasif, menyenangkan, dan saling menguntungkan antara kedua pihak (organisasi dan publiknya). Dalam pencapaian tujuan tersebut, praktisi public relations perlu menguasai seni berkomunikasi atau teknikteknik komunikasi yang efektif.

Frank Jefkins (1998) mengungkapkan humas sebagai semua bentuk komunikasi yang terencana, baik itu ke dalam maupun ke luar, antara suatu organisasi dengan semua khalayaknya dalam rangka mencapai tujuan- tujuan spesifik yang berlandaskan pada saling pengertian. Berikutnya Cutlip, Center, \& Broom (2005) berpendapat bahwa humas adalah fungsi manajemen secara khusus yang mendukung terbentuknya saling pengertian dalam komunikasi, pemahaman, penerimaan, dan kerja sama antara organisasi dengan publiknya.

Dr. Rex Harlow dalam A Model for Public relations Education for Professional Practice yang diterbitkan oleh International Public Relations Association (IPRA) 1978 menyatakan bahwa public relations adalah sebagai berikut: "a public relations is a distinctive
management function which helps
establish and maintain mutual lines
of communications, understanding, acceptance and cooperation between an organization and its publics; involves the management problems or issues; helps management to keep informed on and responsive to public opinion, defines and emphasized the responsibility of management to serve the public interest; help management to keep abreast of an effectively utilize changes; serving as an early warning system to help anticipate trends; and uses research and sound and ethical communication techniques as its principal".

Public relations adalah fungsi manajemen yang khas dan mendukung pembinaan, pemeliharaan jalur bersama antara organisasi dengan publiknya, menyangkut aktivitas komunikasi, pengertian, penerimaan dan kerja sama; melibatkan manajemen untuk mampu menanggapi opini publik; mendukung 
manajemen dalam mengikuti dan memanfaatkan perubahan secara efektif; bertindak sebagai sistem peringatan dini dalam mengantisipasi kecenderungan penggunaan penelitian serta teknik komunikasi yang sehat dan etis sebagai sarana utama (Putra, 1993).

\section{Public Relations World Conference} mendefinisikan humas sebagai gabungan antara seni dan ilmu pengetahuan yang memprediksi kecenderungan, memperkirakan konsekuensi, memberi saran kepada pimpinan organisasi, dan melaksanakan rencana kegiatan sebagaimana yang telah ditetapkan untuk melayani kepentingan publik dan organisasinya. Lebih lanjut, Baskin, Aronof, dan Lattimore (1997) mendefinisikan humas sebagai alat dari manajemen untuk membantu mencapai tujuan organisasi, merumuskan filosofi organisasi, dan menjadi fasilitator dalam perubahan sosial. Pejabat humas menjalin komunikasi dengan seluruh publik, baik internal maupun eksternal, untuk membangun relasi yang positif dan untuk menjaga konsistensi relasi antara tujuan organisasi dan harapan dari lingkungan sosial di sekitar organisasi. Pejabat humas mempunyai tugas dan wewenang untuk mengembangkan, mengimplementasikan, serta melakukan evaluasi kegiatan-kegiatan organisasi yang bertujuan mempertemukan dan menghasilkan rasa saling pengertian antara organisasi dan publiknya.
Howard Bonhan seperti dikutip dalam buku Dasar-Dasar Public Relations Abdurahman (1997) mengungkapkan bahwa humas sebagai suatu seni untuk menciptakan pengertian publik yang lebih baik, yang dapat memperdalam pengertian publik yang lebih baik yang dapat memperdalam kepercayaan publik terhadap seseorang atau organisasi atau badan.

Humas perguruan tinggi sangat berbeda dengan humas perusahaan, instansi pemerintah ataupun Badan Usaha Milik Negara (BUMN). Output dari humas perguruan tinggi adalah mendukung kegiatan pendidikan yang menghasilkan mahasiswa berkualitas, hasil penelitian yang dapat diterapkan pada dunia usaha dan lainnya serta kegiatan-kegiatan lain dalam bentuk pengabdian kepada masyarakat yang dapat membentuk citra positif lembaga perguruan tinggi (Nasution, 2006: 80).

Karakteristik humas perguruan tinggi meliputi praktisi humas perguruan tinggi bersifat seni, praktisi humas cenderung tidak emosional, diplomatis dan human relations, bersifat interaksional kepada mahasiswa, dosen dan karyawan, masyarakat maupun instansi, pemerintah atau swasta, bagian yang membangun kesan dan citra positif lembaga Nasution, (2006). Berdasarkan karakteristik tersebut, fungsi humas di lembaga pendidikan tinggi pada umumnya antara lain adalah sebagai berikut: a) mampu sebagai mediator dalam 
menyampaikan komunikasi secara langsung (komunikasi tatap muka) dan tidak langsung (melalui media) kepada pimpinan lembaga dan publik internal (mahasiswa dan dosen); 2) mendukung dan menunjang kegiatan-kegiatan yang berkaitan dengan mempublikasikan lembaga pendidikan. Dalam hal ini humas bertindak sebagai pengelola informasi kepada publik internal dan publik eksternal. Seperti menyampaikan informasi kepada pers dan promosi; dan 3) menciptakan suatu citra yang positif terhadap lembaga pendidikannya (Nasution, 2006).

Keberadaan humas perguruan tinggi sangat membantu untuk mempromosikan atau mempublikasikan lembaga kepada publik. Selain itu juga sebagai mediator antara pimpinan dengan publiknya. Oleh karena itu, peran humas perguruan tinggi merupakan kunci bagi lembaganya, yaitu: a) humas membantu mencari solusi dalam menyelesaikan masalah antar perguruan tinggi dengan publiknya; b) humas bertindak sebagai mediator untuk membantu pimpinan perguruan tinggi mendengarkan kritikan, saran, dan harapan mahasiswa. Sebaliknya humas juga harus mampu menjelaskan informasi dan kebijakan dari pimpinan perguruan tinggi; dan c) humas membantu mengatasi permasalahan yang terjadi pada perguruan tinggi dengan memberikan masukan kepada pimpinan (Nasution, 2006).
Pentingnya menerapkan strategi public relations dalam mengkomunikasikan Perguruan Tinggi sejalan dengan 'hukum perspektif' yang dikatakan oleh Al Ries dan Jack Trout (dalam Farouk, 2009) bahwa "dampak komunikasi terjadi setelah melewati suatu periode waktu yang diperpanjang”. Hal ini menunjukkan bahwa komunikasi yang berhasil tidak mungkin dapat dilakukan dengan pendekatan yang 'short term' tetapi harus 'long term' Ini berarti perlu adanya program-program public relations.

\section{SIMPULAN}

Perguruan Tinggi Negeri Badan Hukum (PTN BH) di kota Bandung yaitu Institut Teknologi Bandung, Universitas Pendidikan Indonesia, dan Universitas Padjadjaran sudah melakukan implementasi kebijakan keterbukaan informasi publik yaitu Undang-Undang Nomor 14 Tahun 2008 Tentang Keterbukaan Informasi Publik (UU KIP). Humas PTN $\mathrm{BH}$ di kota Bandung telah melakukan peran sebagai expert prescriber (penasehat ahli) dalam implementasi kebijakan keterbukaan informasi seperti memberikan saran kepada pimpinan terkait penentuan SOP pelayanan informasi publik, pembentukan PPID, dan pembuatan sistem pelayanan informasi. Humas PTN BH di kota Bandung telah melakukan peran sebagai communication facilitator (fasilitator komunikasi) dalam implementasi 
kebijakan keterbukaan informasi dengan menjadi penghubung komunikasi, melakukan sosialisasi, dan membentuk sistem pelayanan informasi. Humas PTN BH di kota Bandung telah melakukan peran sebagai problem solving process facilitator (fasilitator proses pemecahan masalah) dalam implementasi kebijakan keterbukaan informasi seperti bentuk kerja sama dengan bagian lain dalam manajemen untuk menyelesaikan masalah terkait implementasi kebijakan keterbukaan informasi seperti pembentukan PPID. Humas PTN BH di kota Bandung telah melakukan peran sebagai communication technician (teknisi komunikasi) atau teknisi humas dengan membuat dan mengembangkan website terlebih website khusus layanan informasi publik dan memproduksi berbagai pesan komunikasi melalui media sosial. Upaya humas dalam memfasilitasi komunikasi antar bagian di internal dan eksternal pada masing-masing PTN BH di kota Bandung sudah baik. Humas sudah melakukan perannya sebagai mediator dalam upaya mencapai pelaksanaan keterbukaan informasi di masing-masing PTN BH di kota Bandung.

\section{DAFTAR PUSTAKA}

Anggoro, M. L. (2000). Teori dan profesi kehumasan serta aplikasinya di indonesia. Jakarta: Bumi Aksara.

Ardianto, E. (2011). Metodologi penelitian untuk public relations kuantitatif dan kualitatif. Bandung: Simbiosa Rekatama Media.

Abdurachman, O. (1997). Dasar-dasar public relations. Bandung: Alumni.

Baskin, O., Arnoff C., \& Lattimore, D. (1997). Public relations: the profession and the practice. 4th ed. New York: McGraw Hill.

Cutlip, S. M., Allen, H. C., \& Glen, M. B. (2005). Effective public relations. New Jersey: Prentice Hall.

Dozier, D. M., Larisa, A. G., \& James, E. G. (1995). Manager's guide to excellence in public relations and communication management. London: Routledge.

Farouk, U. (2009). Peran public relations di perguruan tinggi negeri (ptn). DIALOGUE, $6(1), 68-77$.

Gifari, F. (2017). Strategi asia pr dalam memperkuat hubungan media dengan forum wartawan otomotif (forwot) asiapr strategy in strengthening media relations with forum, PRofesi Humas, 1(2), 101-111. Retrieved from http://jurnal.unpad.ac.id/ profesi-humas/article/view/11665/7237.

Harlow, R. (1978). A model for public relations education for profesional practic. International Public relations Association.

Henny, S. (2017). Personal interview.

Jessica, S. (2018). Aktivitas public relations angkasa pura ii dalam menangani pemberitaan negatif terminal 3 bandara soekarno-hatta the activity of public relations of angkasa pura ii in handling negative news terminal 3 soekarno - hatta airport, PRofesi Humas, 2(2), 119-135. Retrieved from http://jurnal.unpad.ac.id/ profesi-humas/article/view/12087/7824.

Jefkins, F. (2004). Public relations. Edisi 5. Jakarta: Erlangga.

Nasution, Z. (2010). Manajemen humas di 
lembaga pendidikan. Malang: UMM Press. Nazir, M. (2006). Metode penelitian. Jakarta: Ghalia Indonesia.

Peraturan Komisi Informasi Nomor 1 Tahun 2010 Tentang Standar Layanan Informasi.

Peraturan Menteri Riset, Teknologi, dan Pendidikan Tinggi Republik Indonesia Nomor 75 Tahun 2016 Tentang Layanan Informasi Publik di Lingkungan Kementerian Riset, Teknologi, dan Pendidikan Tinggi.

Peraturan Pemerintah Republik Indonesia Nomor 4 Tahun $2014 \quad$ Tentang Penyelenggaraan Pendidikan Tinggi dan Pengelolaan Perguruan Tinggi.
Peraturan Pemerintah Republik Indonesia Nomor 61 Tahun 1999 tentang Penetapan Perguruan Tinggi Negeri (PTN) sebagai Badan Hukum.

Peraturan Pemerintah Republik Indonesia Nomor 61 Tahun 2010 Tentang Pelaksanaan Undang - Undang Nomor 14 Tahun 2008. Putra, I. G. N. (1999). Manajemen hubungan masyarakat. Yogyakarta: Universitas Atmajaya Yogyakarta.

Ruslan, R. (2014). Manajemen public relations dan media komunikasi. Jakarta: Raja Grafindo Persada.

Undang - Undang Nomor 14 Tahun 2008 tentang Keterbukaan Informasi Publik. 